\title{
Science in action
}

Citation for published version (APA):

Bijker, W. E. (1988). Science in action: How to follow scientists and engineers through society. Technology and Culture, 29(4), 982-983.

Document status and date:

Published: 01/01/1988

Document Version:

Publisher's PDF, also known as Version of record

\section{Please check the document version of this publication:}

- A submitted manuscript is the version of the article upon submission and before peer-review. There can be important differences between the submitted version and the official published version of record.

People interested in the research are advised to contact the author for the final version of the publication, or visit the DOI to the publisher's website.

- The final author version and the galley proof are versions of the publication after peer review.

- The final published version features the final layout of the paper including the volume, issue and page numbers.

Link to publication

\footnotetext{
General rights rights.

- You may freely distribute the URL identifying the publication in the public portal. please follow below link for the End User Agreement:

www.umlib.nl/taverne-license

Take down policy

If you believe that this document breaches copyright please contact us at:

repository@maastrichtuniversity.nl

providing details and we will investigate your claim.
}

Copyright and moral rights for the publications made accessible in the public portal are retained by the authors and/or other copyright owners and it is a condition of accessing publications that users recognise and abide by the legal requirements associated with these

- Users may download and print one copy of any publication from the public portal for the purpose of private study or research.

- You may not further distribute the material or use it for any profit-making activity or commercial gain

If the publication is distributed under the terms of Article $25 \mathrm{fa}$ of the Dutch Copyright Act, indicated by the "Taverne" license above, 
Science in Action: How to Follow Scientists and Engineers through Society.

By Bruno Latour. Cambridge, Mass.: Harvard University Press, 1987. Pp. viii +274; figures, notes, appendixes, bibliography, index. $\$ 25.00$.

Bruno Latour takes his entry "through the back door of science in the making, not through the more grandiose entrance of ready made science" (p. 4) and reports compellingly on scientists and engineers as they construct facts, artifacts, and society.

In the first part of Science in Action, Latour shows how scientific facts and technical machines emerge, and that it is this construction process, science and technology in the making, that we should study to understand its results, ready-made science and technology. Both are as intimately tied together as the two sides of Janus's head: the ready-made side arguing that "once a machine works, people will be convinced," while the in-the-making side says that "the machine will work when all the relevant people are convinced" (p. 10). Facts and machines do not have intrinsic qualities that can be evoked to explain their development; their fate is in later users' hands. Thus, the qualities of facts and machines are the consequence, not the cause, of a collective action. Following this advice will plunge you into controversies-going from daily life to science is not like going from noise to quiet, from passion to reason. "It is like reading a law book and then going to court to watch a jury wavering under the impact of contradictory evidence" (p. 30). Latour makes it clear that such an approach implies that we should no longer try to decide about the objectivity or subjectivity of a statement or the working or nonworking of a machine, but follow the fate of statements and machines instead, as they are made objective or working (or the opposite) through the hands of engineers, scientists, and other users.

In the second part, the author identifies the mechanisms by which engineers and scientists give strength to their statements and machines in order to see them become objective and working. Here Latour convincingly criticizes the standard "diffusion model" as contrasted with the "translation model." In the diffusion model, facts and machines seem to have a momentum of their own, and through some ingenious mating system they reproduce one another. "They seem to move ... . without people. More fantastic, it seems they would have existed even without people" (p. 133). In the translation model, Diesel's engine, for example, is not described as an idea that was always out there and needed only to be discovered, but as a constantly changing combination of elements, ushered forward while being modified by human engineers, financiers, licensers, and users. The diffusion model necessarily creates a distinction between "technoscience" and society, between humans and nonhumans, whereas the translation model can provide a symmetrical analysis of these various elements. Thus, a distinction between social and technical is not to be made a 
priori by the researchers but should be analyzed as the result of the engineers' work. In the final section, Latour uses the "network" concept to analyze further the relations of facts, machines, and society. In so doing, he illuminates the role of scale models, mathematical formulae, and metrology.

What does this book offer to the historian of technology? It does not present new historical case studies, nor does it provide a straightforward theory of technological development. It is, however, addressing one of the central concerns of the SHOT tradition-the relationship between technology and its context. Latour radically transcends the distinction between technology and its context by purging the reader's mind of worn-out concepts and by developing a completely new vocabulary to describe and analyze the seamless web of technology, science, and society. He can do this only by building on the rich tradition of recent history of technology, using, for example, numerous articles from Technology and Culture.

This is the kind of book that may, at the end of its story, leave you exasperated, perhaps even furious at the author who has been leading you to conclusions you never dreamed you would uphold. If you are infuriated, for example, by the merging of human and nonhuman factors or the elimination of nature, don't throw the book against the wall-read it again. This is an important work for the history of technology, and for related disciplines such as the history and sociology of science and business as well.

\section{WIEBE E. BIJKER}

Dr. BIJKkR is assistant professor at the University of Limburg. He coedited, with Thomas P. Hughes and Trevor J. Pinch, The Social Construction of Technological Systems (Cambridge, Mass.: MIT Press, 1987) and coedits, with Pinch and W. Bernard Carlson, an MIT Press monograph series on the integrated analysis of history and sociology of technology called Inside Technology.

Changing Order: Replication and Induction in Scientific Practice. By H. M. Collins. Beverly Hills, Calif.: Sage, 1985. Pp. viii + 187; notes, bibliography, indexes. $\$ 25.00$ (cloth); $\$ 12.50$ (paper).

Harry Collins has been one of the major European players in the "new" post-Mertonian sociology of science. He is one of the authors of its "radical programme of relativism," and as such has long been concerned to show that science is both completely socially constructed and context dependent.

His major means for doing so have been to demonstrate some variability in the conditions of production of science and to choose variability that could be explained only with reference to social factors. For Collins, the major focus has been on the Achilles heel of scientific positivism-replication. In demonstrating the impossibility of total replication, and in elucidating the conditions under which replicatory 